\title{
PENGARUH PEMBERIAN MINUMAN BERKARBOHIDRAT SEBELUM LATIHAN TERHADAP KADAR GLUKOSA DARAH ATLET
}

\author{
Erni Rukmana, Deny Yudi Fitranti*) \\ Program Studi Ilmu Gizi Fakultas Kedokteran Universitas Diponegoro \\ J1.Dr.Sutomo No.18, Semarang, Telp (024) 8453708, Email : gizifk@ undip.ac.id
}

\begin{abstract}
Background: Blood glucose availability during exercise is one of the factors affecting athelete's performance enhancement. Carbohydrate beverage ingestion before exercise can help maintaining athlete's blood glucose and delaying fatigue. Carbohydrate beverage is a fluid that can supply energy during exercise or match. Ingestion of $6-$ $8 \%$ carbohydrate beverage during exercise or match can also help enhancing athlete's performance by delaying fatigue.

Objective: The purpose of this study was to determine the effect of carbohydrate beverage ingestion 15 minutes before exercise on athlete's blood glucose level.

Method: This study was in the field of true experimental experiment with pre post randomized controlled group design. Eighteen male soccer players between the ages of 15-18 in Pusat Pendidikan Pelatihan dan Latihan Pelajar (PPLP) Jawa Tengah participated in this study. The subjects have given $250 \mathrm{ml}$ carbohydrate beverage and water (control). Both carbohydrate beverage and water was given 15 minutes before 10 minutes of exercise. Blood glucose was measured before and after 10 minutes of exercise.

Result: There was significant difference in blood glucose level before and after 10 minutes exercise in carbohydrate beverage and control group $(p<0.05)$. The average of decreased blood glucose level in carbohydrate beverage group was smaller than the control group, but based statistic There was no significant difference in blood glucose level decrease between carbohydrate beverage group and control $(p=0.264)$

Conclusion: Ingestion of carbohydrate beverage before excersice in athletes can minimize blood glucose level decrease during exercise compare with control group.

Keywords: carbohydrate beverage; blood glucose levels; atheletes
\end{abstract}

\begin{abstract}
ABSTRAK
Latar Belakang: Ketersediaan glukosa darah selama latihan merupakan faktor yang berpengaruh terhadap peningkatan performa atlet. Pemberian minuman yang mengandung karbohidrat sebelum latihan dapat membantu mempertahankan kadar glukosa darah dan menunda kelelahan. Minuman berkarbohidrat dapat menyuplai energi selama latihan maupun pertandingan. Pemberian minuman dengan kandungan karbohidrat 6-8\% selama latihan atau pertandingan dapat membantu meningkatkan performa atlet dengan menunda kelelahan.

Tujuan: Penelitian ini bertujuan mengetahui pengaruh pemberian minuman berkarbohidrat 15 menit sebelum latihan terhadap kadar glukosa darah atlet.

Metode: Penelitian ini merupakan penelitian true eksperimental dengan rancangan pre-post randomized controlled gorup design. Jumlah subjek 18 atlet sepak bola usia 15-18 tahun di Pusat Pendidikan Pelatihan dan Latihan Pelajar (PPLP) Jawa Tengah yang berpartisipasi dalam penelitian. Subjek penelitian menerima intervensi pemberian minuman berkarbohidrat dan air (kontrol) sebanyak $250 \mathrm{ml}$. Minuman diberikan 15 menit sebelum latihan lari 10 menit. Kadar glukosa darah diukur sebelum dan setelah lari 10 menit.

Hasil: Terdapat perbedaan kadar glukosa darah sebelum dan setelah lari 10 menit baik pada kelompok minuman berkarbohidrat maupun kontrol ( $p<0.05)$. Rata-rata penurunan kadar glukosa darah pada kelompok minuman berkarbohidrat lebih kecil daripada kelompok kontrol, akan tetapi menurut statistik tidak ada perbedaan yang bermakna pada kadar glukosa darah antara kelompok minuman berkarbohidrat dan kelompok kontrol $(p=0.264)$.

Simpulan: Pemberian minuman minuman berkarbohidrat sebelum latihan pada atlet dapat memperkecil penurunan kadar glukosa darah selama latihan dibandingkan kelompok kontrol.
\end{abstract}

Kata kunci: minuman berkarbohidrat; kadar glukosa darah; atlet

\section{PENDAHULUAN}

Karbohidrat merupakan sumber energi utama yang digunakan dalam tubuh selain lemak dan protein. Pada saat latihan, karbohidrat dapat dipecah sebagai energi melalui mekanisme aerobik dan anaerobik. Metabolisme karbohidrat menjadi energi terjadi secara aerobik pada latihan dengan intensitas ringan dan sedang. Energi yang berasal dari proses aerobik mula-mula berasal dari pemecahan glikogen otot menjadi glukosa. ${ }^{1}$ Apabila dalam tubuh tidak diperoleh dari konsumsi, laju pemecahan glukosa yang berasal 
dari glikogen hati tidak akan cukup untuk memenuhi pemakaian glukosa oleh otot dan jaringan lain. ${ }^{2,3}$

Ketersediaan glukosa darah selama latihan merupakan faktor yang berpengaruh terhadap performa atlet. Apabila kadar glukosa darah menurun, fungsi sel otak terganggu karena sel saraf tidak menyimpan karbohidrat akibatnya akan berdampak pada penurunan peforma atlet. ${ }^{1,3}$ Cairan yang mengandung karbohidrat dan elektrolit selama dan setelah pertandingan akan membantu menjaga kadar glukosa darah, menurunkan risiko dehidrasi, dan hipotermia. ${ }^{4,5}$ Selain itu, konsumsi cairan karbohidrat sebelum pertandingan dapat mengoptimalkan konsentrasi glukosa darah melalui pasokan karbohidrat. ${ }^{5-7}$ Salah satu cara untuk penyediaan karbohidrat dalam tubuh yaitu menggunakan minuman berkarbohidrat. ${ }^{1,8}$

Minuman karbohidrat dapat menyuplai energi selama latihan maupun pertandingan. ${ }^{1,8}$ Pemberian minuman dengan kandungan karbohidrat 6-8\% selama latihan atau pertandingan dapat membantu meningkatkan performa atlet dengan menunda kelelahan. ${ }^{4,9,10}$ Penelitian yang dilakukan di Australia menyebutkan bahwa atlet yang mengkonsumsi minuman berkarbohidrat sebelum dan selama latihan cycling selama 47 menit memiliki kadar glukosa darah lebih stabil dibanding kelompok placebo. ${ }^{11}$ Penelitian yang dilakukan di India didapatkan hasil bahwa air tebu dengan karbohidrat (sukrosa) 6\% selama dan setelah latihan menggunakan bicycle ergometer dapat mempertahankan kadar glukosa darah pada atlet laki-laki. ${ }^{4}$ Atlet yang diberikan minuman karbohidrat $6 \%$ dapat melakukan latihan sprint lebih cepat dibandingkan atlet yang mendapatkan placebo. ${ }^{12}$ Penelitian yang dilakukan di India menyebutkan konsumsi minuman berkarbohidrat (dekstrosa dan gula) 6\% sebelum latihan lari menggunakan treadmill dapat meningkatkan energi yang tersedia untuk kerja otot. ${ }^{5}$ Pemberian minuman karbohidrat 6\% menyediakan jumlah optimal karbohidrat untuk palatabilitas, berperan dalam mempercepat pengosongan lambung, dan diperlukan untuk meningkatkan kinerja atlet. $^{5}$ Sedangkan, pemberian minuman dengan kandungan karbohidrat $>8 \%$ akan menginduksi kerja insulin sehingga kadar glukosa darah menurun, selain itu dapat memperlambat proses absorpsi cairan di dalam tubuh dan menimbulkan gangguan pencernaan. ${ }^{13}$ Minuman berkarbohidrat komersial mengandung kombinasi dari jenis karbohidrat (sukrosa, glukosa, fruktosa, dan glukosa polimer). Penelitian menunjukkan bahwa apabila beberapa jenis karbohidrat digunakan akan meningkatkan penyerapan cairan dan membantu mengurangi risiko gangguan gastrointestianal. ${ }^{1,5}$

Kebiasaan atlet dalam hal konsumsi minuman karbohidrat sebelum latihan masih jarang dilakukan. Minuman karbohidrat banyak digunakan selama latihan dan pemulihan bukan pada saat sebelum latihan. Pada beberapa penelitian lain menunjukkan perubahan metabolik yang berhubungan dengan pemberian cairan karbohidrat 15-60 menit sebelum latihan yang memiliki potensi untuk meningkatkan performa dengan menunda kelelahan atlet. ${ }^{5,6,14}$

Berdasarkan latar belakang tersebut, peneliti tertarik untuk melakukan penelitian tentang pengaruh pemberian minuman berkarbohidrat sebelum latihan terhadap glukosa darah atlet sepak bola usia 15-18 tahun karena pada atlet usia tersebut masih dalam masa petumbuhan sehingga dibutuhkan tambahan asupan karbohidrat selama latihan ataupun pertandingan. ${ }^{10}$ Hasil penelitian ini diharapkan dapat memberikan informasi kepada atlet serta pelatih mengenai pengaruh pemberian minuman berkarbohidrat terhadap kadar glukosa darah selama latihan.

\section{METODE}

Penelitian ini dilaksanakan di Pusat Pendidikan Pelatihan dan Latihan Pelajar (PPLP) Jawa Tengah pada bulan Agustus 2013. Penelitian ini merupakan penelitian true exsperimental dengan rancangan pre-post randomized controlled group design. Jumlah sampel minimal untuk penelitian ini adalah 18 orang yang akan dibagi menjadi dua kelompok yaitu kelompok perlakuan dan kelompok kontrol. Subjek penelitian diambil secara simple random sampling setelah terlebih dulu diberikan informed consent secara verbal dan memenuhi kriteria inklusi antara lain berusia 15-18 tahun, intensitas latihan intermidiate (50-70\% dari denyut nadi maksimal (220-usia)), $\mathrm{Vo}_{2}$ maksimal 45,2-50,9 $\mathrm{ml} / \mathrm{kg} / \mathrm{menit}$, cukup tidur, tidak sedang cidera atau dalam perawatan dokter, serta tidak memiliki riwayat kesehatan yang berhubungan dengan jantung, paru-paru, maupun diabetes.

Variabel bebas pada penelitian ini adalah minuman komersial yang mengandung karbohidrat sederhana dan kompleks (glukosa, fruktosa dan maltodextrin) dalam $250 \mathrm{ml}$ dan memiliki kadar karbohidrat $6 \%$ serta elektrolit. Minuman ini diberikan 15 menit sebelum latihan lari selama 10 menit. Sebagai kontrol, subjek diberikan perlakuan lain berupa pemberian air dalam jumlah dan frekuensi yang sama dengan pemberian minuman 
berkarbohidrat. Variabel terikat pada penelitian ini adalah kadar glukosa darah sewaktu yang diukur sebanyak dua kali, yakni sebelum dan setelah latihan lari 10 menit pada masing-masing perlakuan.

Data yang dikumpulkan meliputi data antropometri (berat badan dan tinggi badan), persen lemak tubuh, denyut nadi maksimal, dan data kapasitas aerobik $\left(\mathrm{VO}_{2}\right.$ maks), serta data kadar glukosa darah. Berat badan diukur menggunakan timbangan injak digital dengan ketelitian $0.1 \quad \mathrm{~kg}$. Tinggi badan diukur menggunakan microtoise dengan batas ukur 200 $\mathrm{cm}$ dan ketelitian $0.1 \mathrm{~cm}$. Persen lemak tubuh diukur menggunakan Bioelectric Impedance Analyzer (BIA) dengan merek Omron body fat analyzer digital weighing scale HBF-200. Kapasitas aerobik atlet $\left(\mathrm{VO}_{2}\right.$ maks) diukur melalui lari $2.4 \mathrm{~km}$ menit (Cooper test). Waktu yang dibutuhkan untuk menyelesaikan tes lari diukur menggunakan stopwatch dengan ketelitian 0.01 detik. Pengambilan sampel darah untuk pengukuran kadar glukosa darah dilakukan oleh laboran di laboratorium ' $\mathrm{X}$ ' melalui pembuluh kapiler pada jari dengan menggunakan glucose meter.

Penelitian ini berlangsung selama 3 hari berurutan. Hari pertama dan kedua merupakan pengambilan data awal, yaitu pengambilan denyut nadi maksimal dan pengukuran $\mathrm{Vo}_{2}$ maks dengan metode lari $2.4 \mathrm{~km}$ (cooper test). Pengambilan data antropometri, persen lemak tubuh di hari ketiga sebelum dilaksanakannya intervensi. intervensi kelompok perlakuan diberikan minuman berkarbohidrat dan kelompok kontrol diberikan placebo.

Analisis deskriptif digunakan untuk melihat gambaran karakteristik subjek. Analisis bivariate diawali dengan uji normalitas data Shapiro-Wilk, kemudian dilanjutkan dengan uji Mann Whitney untuk melihat perbedaan karakteristik kedua subjek. Perbedaan kadar glukosa darah sebelum dan setelah lari 10 menit pada kelompok minuman berkarbohidrat dan kontrol menggunakan uji paired test, sedangkan uji Independent $t$ test untuk melihat perbedaan dan penurunan kadar glukosa darah sebelum dan setelah lari 10 menit antara kelompok minuman berkarbohidrat dan kontrol.

\section{HASIL PENELITIAN \\ Karakteristik Subjek Penelitian}

Karakteristik subjek penelitian meliputi usia, berat badan, tinggi badan, Indeks Massa Tubuh (IMT), persen lemak tubuh, dan $\mathrm{Vo}_{2}$ maks disajikan dalam Tabel 1.

Tabel 1. Karakteristik subjek penelitian ( $\mathrm{n}=18)$

\begin{tabular}{llll}
\hline Karakteristik Subjek & $\begin{array}{l}\text { Kelompok } \\
\text { minuman } \\
\text { berkarbohidrat } \\
(\mathrm{n}=9)\end{array}$ & Kelompok kontrol $(\mathrm{n}=9)$ & $p$ \\
\cline { 2 - 4 } & Rerata \pm SB & Rerata \pm SB & \\
\hline Usia (tahun) & $16.00 \pm 0.86$ & $16.44 \pm 0.52$ & 0.251 \\
Berat Badan $(\mathrm{kg})$ & $62.10 \pm 6.70$ & $63.78 \pm 5.38$ & 0.659 \\
Tinggi Badan $(\mathrm{cm})$ & $170.44 \pm 7.63$ & $170.70 \pm 3.53$ & 0.965 \\
IMT $\left(\mathrm{kg} / \mathrm{cm}^{2}\right)$ & $21.35 \pm 1.59$ & $21.93 \pm 1.73$ & 0.200 \\
Persen lemak tubuh $(\%)$ & $15.60 \pm 3.45$ & $16.85 \pm 2.66$ & 0.216 \\
$\mathrm{Vo}_{2}$ maks $(\mathrm{ml} / \mathrm{kg} /$ menit $)$ & $48.94 \pm 1.46$ & $49.11 \pm 0.92$ & 0.924 \\
\hline
\end{tabular}

*mann-whitney $U(p>0.05)$

Tabel 1 menunjukkan tidak ada perbedaan bermakna $(p>0.05)$ antara kelompok minuman berkarbohidrat dan kontrol berdasarkan variabel usia, berat badan, tinggi badan, indeks massa tubuh, persen lemak tubuh, dan $\mathrm{Vo}_{2}$ maks. Hal ini menunjukkan kedua kelompok pada penelitian ini memiliki karakteristik yang sama.

Distribusi frekuensi status gizi dan persen lemak tubuh pada kelompok minuman berkarbohidrat dan kontrol disajikan dalam Tabel 2. 
Tabel 2. status gizi dan persen lemak tubuh

\begin{tabular}{llll}
\hline Variabel & $\begin{array}{l}\text { Kelompok } \\
\text { minuman } \\
\text { berkarbohidrat } \\
(\mathrm{n}=9)\end{array}$ & $\begin{array}{l}\text { Kelompok } \\
\text { kontrol }(\mathrm{n}=9)\end{array}$ & Total subjek (n=18) \\
& & & \\
\hline $\begin{array}{l}\text { Status gizi }\left(\mathrm{kg} / \mathrm{m}^{2}\right) \\
\text { kurang }\end{array}$ & 0 & $11.1 \%$ & $5.6 \%$ \\
baik & $100 \%$ & $88.9 \%$ & $94.4 \%$ \\
$\begin{array}{l}\text { Persen lemak tubuh }(\%) \\
\text { kurang }\end{array}$ & $22.2 \%$ & $11.1 \%$ & $16.7 \%$ \\
baik & $55.6 \%$ & $77.8 \%$ & $66.7 \%$ \\
lebih & $22.2 \%$ & $11.1 \%$ & $16.7 \%$ \\
\hline
\end{tabular}

Penelitian ini menunjukkan $99.4 \%$ subjek mempunyai status gizi baik $\left(18.5-25.5 \mathrm{~kg} / \mathrm{m}^{2}\right)$ dan $66.7 \%$ persen lemak tubuh baik (15-18\%), hanya terdapat $11.1 \%$ subjek mempunyai status gizi kurang pada kelompok kontrol.

\section{Perbedaan Kadar Glukosa Darah Sebelum dan Setelah Lari 10 menit}

Perbedaan kadar glukosa darah sebelum dan setelah lari 10 menit pada perlakuan minuman berkarbohidrat dan kontrol disajikan dalam Tabel 3.

Tabel 3. Perbedaan kadar glukosa darah sebelum dan setelah lari 10 menit

\begin{tabular}{llll}
\hline \multirow{2}{*}{ Kelompok } & \multicolumn{2}{c}{ Rerata \pm SB } & \multirow{2}{*}{$p^{\mathrm{a}}$} \\
\cline { 2 - 3 } & $\begin{array}{l}\text { Kadar glukosa darah } \\
\text { sebelum }(\mathrm{mg} / \mathrm{dl})\end{array}$ & $\begin{array}{l}\text { Kadar glukosa darah } \\
\text { setelah }(\mathrm{mg} / \mathrm{dl})\end{array}$ & 0.000 \\
$\begin{array}{l}\text { Minuman } \\
\text { berkarbohidrat (n=9) }\end{array}$ & $98.33 \pm 10.24$ & $72.55 \pm 6.57$ & 0.012 \\
\hline \begin{tabular}{l} 
Kontrol (n=9) \\
\hline$P^{\mathrm{b}}$
\end{tabular} & $113.22 \pm 26.42$ & $72.44 \pm 17.33$ & \\
\hline
\end{tabular}

${ }^{a}$ paired t-test perbedaan kadar glukosa darah pada kelompok minuman karbohidrat dan kelompok kontrol , terdapat perbedaan yang bermakna $(\mathrm{p}<0.05)$

${ }^{\mathrm{b}}$ independent $t$ test perbedaan kadar glukosa darah antara kelompok minuman karbohidrat dan kelompok kontrol , tidak terdapat perbedaan yang bermakna $(\mathrm{p}>0.05)$

Penelitian ini menunjukkan bahwa terdapat perbedaan yang bermakna pada kadar glukosa darah sebelum dan setelah lari 10 menit baik pada kelompok minuman berkarbohidrat maupun kontrol $(p<0.05)$, sedangkan antara kelompok minuman karbohidrat dan kelompok kontrol tidak terdapat perbedaan yang bermakna kadar glukosa darah sebelum dan setelah lari 10 menit $(p>0.05)$.

Penurunan kadar glukosa darah sebelum dan setelah lari 10 menit pada kelompok minuman berkarbohidrat dan kontrol disajikan dalam Tabel 4.

Tabel 4. Penurunan kadar glukosa darah

\begin{tabular}{lcc}
\hline \multicolumn{1}{c}{ Variabel } & Rata-rata \pm & $p$ \\
SB & & $0.264^{*}$ \\
$\begin{array}{l}\text { Penurunan kadar glukosa darah } \\
(\mathrm{mg} / \mathrm{dl})\end{array}$ & $25.77 \pm 7.710$ & \\
$\begin{array}{l}\text { Kelompok minuman berkarbohidrat } \\
\text { Kelompok kontrol }\end{array}$ & $40.77 \pm 38.10$ & \\
\hline
\end{tabular}

*Independent $t$ test $(p>0.05)$

Tabel 4 menunjukkan bahwa tidak terdapat perbedaan yang bermakna pada penurunan kadar glukosa darah antara kelompok minuman berkarbohidrat dan kontrol $(p>0.05)$. 


\section{PEMBAHASAN}

Subjek penelitian merupakan atlet sepak bola remaja laki-laki berusia 15-18 tahun. Berdasarkan teori, remaja laki-laki mengalami pertumbuhan massa otot yang lebih banyak dan memiliki komposisi lemak tubuh yang cenderung sedikit. ${ }^{15}$ Penelitian ini memberikan hasil status gizi dan persen lemak tubuh baik (masing-masing 94\% dan 66.7\%). Penelitian lain yang dilakukan pada atlet sepak bola di Persatuan Sepak Bola Kudus (PERSIKU) menunjukkan bahwa status gizi dan persen lemak tubuhnya juga baik (masingmasing $83.33 \%$ dan $72.22 \%) .{ }^{16}$ Komposisi lemak tubuh berpengaruh terhadap kadar glikogen otot, sehingga berpengaruh pula terhadap kadar glukosa darah. Glukosa darah dapat dipecah dari cadangan glikogen otot apabila tubuh membutuhkan. ${ }^{1} \mathrm{Vo}_{2}$ maksimal atlet sepak bola di PPLP mempunyai nilai rata-rata baik. $\mathrm{Vo}_{2}$ maks menggambarkan kebugaran atlet dan seberapa jauh atlet dapat mengoptimalkan kapasitas aerobiknya. Kapasitas aerobik, intensitas latihan dan durasi latihan mempengaruhi kadar glukosa darah. Pada latihan intensitas sedang dengan durasi 20 menit, glukosa merupakan sumber energi yang dominan. Latihan dengan intensitas sedang dapat menurunkan tingkat kadar glukosa lebih besar dari pada latihan dengan intensitas tinggi. Hal ini, disebabkan hormon- hormon yang mengontrol kadar glukosa darah. $^{21}$

Glukosa merupakan bentuk karbohidrat sederhana yang berfungsi untuk menyuplai cadangan energi dalam jangka pendek. ${ }^{9}$ Glukosa akan dipecah menjadi energi. Sisanya diserap dalam jumlah besar ke dalam darah serta dikonversikan di dalam hati sebagai glikogen dan sebagian lagi akan disebarkan ke seluruh tubuh. ${ }^{2}$ Sumber energi utama yang didapat dari karbohidrat menghasilkan simpanan glukosa di dalam tubuh, yakni glukosa darah, glikogen otot, dan glikogen hati. ${ }^{1}$ Kadar glukosa darah normal berada pada nilai $80-100 \mathrm{mg} / \mathrm{dl}^{3}{ }^{3}$ Rata-rata kadar glukosa darah sebelum lari pada kedua kelompok atlet tidak ada perbedaan, walaupun rata-rata kadar glukosa darah pada kelompok kontrol diatas $100 \mathrm{mg} / \mathrm{dl}$. Kadar glukosa darah tidak langsung meningkat setelah konsumsi minuman yang mengandung karbohidrat sederhana. Peningkatan kadar glukosa darah akan terjadi setelah 15 menit sampai 30 menit dari konsumsi minuman karbohidrat sebelum latihan. ${ }^{17}$

Hasil penelitian ini menunjukkan terjadi penurunan kadar glukosa darah selama latihan 10 menit baik pada kelompok minuman berkarbohidrat maupun kontrol. Pada saat seseorang berpuasa atau sedang melakukan aktivitas (latihan olahraga, bekerja) akan menyebabkan turunnya kadar glukosa darah menjadi $60 \mathrm{mg} / \mathrm{dl}{ }^{18}$ Selama latihan fisik akan terjadi peningkatan penggunakan glikogen otot dan glukosa darah sesuai dengan beratnya aktifitas fisik. Penurunan kadar glukosa darah pada kelompok minuman berkarbohidrat lebih kecil daripada kontrol. Kandungan karbohidrat pada minuman berkarbohidrat mampu menjaga kadar glukosa darah agar tidak dibawah batas $60 \mathrm{mg} / \mathrm{dl}$ daripada kontrol. Kontrol yang digunakan adalah air, minuman yang tidak mengandung karbohidrat hanya mampu mempertahankan hidrasi tubuh. Tujuan utama mengkonsumsi karbohidrat sebelum latihan adalah untuk mempertahankan konsentrasi glukosa darah yang bertujuan agar tidak terjadi hipoglikemi pada saat latihan dan mampu menyediakan sumber energi didalam darah dan mempertahankan cadangan glikogen dalam otot. ${ }^{19}$

Penelitian ini juga menunjukkan rata-rata perbedaan penurunan kadar glukosa darah pada kelompok minuman berkarbohidrat lebih kecil daripada kelompok kontrol, akan tetapi perbedaan penurunan kadar glukosa darah antara kelompok minuman berkarbohidrat dan kelompok kontrol tidak signifikan. Pemberian minuman berkarbohidrat yang mengandung karbohidrat 6$8 \%$ selama latihan atau pertandingan dapat membantu mempertahankan kadar glukosa darah dan menjaga ketersediaan glikogen otot. ${ }^{7}$ Glukosa, fruktosa, dan glukosa polimer (maltodekstrin) merupakan jenis karbohidrat yang baik selama berolahraga dikarenakan dapat diabsorpsi secara lebih baik. ${ }^{1,4}$ Glukosa dan fruktosa berperan dalam peningkatan kadar glukosa darah secara cepat, sedangkan maltodekstrin sebagai simpanan glikogen dalam tubuh. Apabila beberapa jenis karbohidrat digunakan secara bersamaan akan meningkatkan penyerapan cairan dan membantu mengurangi risiko gangguan gastrointestianal. ${ }^{4} \mathrm{Di}$ samping peran karbohidrat sebagai sumber energi selama berolahraga, natrium dan kalium sebagai sumber elektrolit dapat membantu absorpsi glukosa dengan cepat apabila ditambahkan bersama sumber karbohidrat dalam minuman. ${ }^{3}$ Rata-rata perbedaan penurunan kadar glukosa darah antara kelompok minuman berkarbohidrat dan kontrol juga pengaruh dari kandungan elektrolit dalam minuman berkarbohidrat.

Penelitian yang dilakukan di Australia menyebutkan bahwa atlet yang mengkonsumsi minuman berkarbohidrat sebelum dan selama latihan cycling selama 47 menit memiliki kadar 
glukosa darah lebih stabil dibanding kelompok placebo. ${ }^{11}$ Penelitian di Amerika menyebutkan bahwa asupan karbohidrat sederhana maupun kompleks 15 menit dan 60 menit sebelum latihan dapat mempertahankan kadar glukosa darah. ${ }^{20} \mathrm{Hal}$ ini menunjukkan bahwa karbohidrat yang terkandung dalam minuman yang dikonsumsi atlet sebelum olahraga mampu memperkecil penurunan kadar glukosa darah sehingga dapat mempertahankan kecukupan energi.

Keterbatasan penelitian ini adalah tidak dilaksanakannya pengukuran kadar insulin dan glukagon, hormon yang berperan dalam metabolisme glukosa selama latihan.

\section{SIMPULAN}

Penurunan kadar glukosa darah pada minuman berkarbohidrat lebih kecil yakni $25.77 \pm$ $7.7 \mathrm{mg} / \mathrm{dl}$, sedangkan pada kelompok kontrol sebesar $40.77 \pm 38.10 \mathrm{mg} / \mathrm{dl}$. Pemberian minuman berkarbohidrat dapat memperkecil penurunan kadar glukosa darah dibandingkan kelompok kontrol.

\section{SARAN}

1. Pemberian minuman karbohidrat $6 \%$ sebelum latihan atau pertandingan dapat diterapkan pada atlet untuk menjaga kadar glukosa darah.

2. Diperlukan penelitian lebih lanjut mengenai pengaruh pemberian minuman karbohidrat $6 \%$ sebelum latihan untuk mengurangi kelelahan pada atlet.

3. Diperlukan penelitian lebih lanjut mengenai pengaruh hormon insulin dan glukagon, hormon yang berperan dalam mempertahankan kadar glukosa darah.

\section{UCAPAN TERIMA KASIH}

Puji syukur penulis panjatkan kepada Allah SWT atas limpahan rahmat-Nya kepada penulis. Terimakasih penulis sampaikan kepada subjek penelitian, pengurus, serta pelatih sepak bola di Pusat Pendidikan dan Latihan Pelajar (PPLP) Jawa Tengah yang telah bekerja sama dan membantu terlaksananya penelitian ini. Selain itu, ucapan terima kasih juga disampaikan kepada dosen pembimbing yang telah membimbing penelitian ini serta dosen penguji yang telah memberikan masukan dan saran dalam penelitian ini, keluarga dan teman-teman atas doa dan dukungannya.

\section{DAFTAR PUSTAKA}

1. Heater HF, Lisa AB, Alan EM. Practical application in sports nutrition. Massachusetts:
Jones and Bartlett Publisher; 2006.p.82-83; 22426; 326; 434; 470-75.

2. Alv A, Williams C, Nicholas CW, Foskett A. The influence of carbohydrate-electrolyte ingestion on soccer skill performance. Medicine \& Science In Sports \& Exercise 2007; 3911-1969.

3. Willam MH. Nutrition for health, finess, and sport. $8^{\text {th }}$ edition. New York: Mc graw-Hiil Companies, inc; 2007.p.118-20; 122; 124; 125; 128; 129; 131.

4. Kalpana K, Lal PR, Kusuma DK, Khanna GL. The effects of ingestion of sugarcane juice and commercial sports drink on cycling performance of athletes in comparison to plain water. Asran j Sports Med 2013; 04 (No x) xxx.

5. Singh A, Chaudhary S, Sandhu JS. Efficacy of pre exercise carbohydrate drink (gatorade) on the recovery heart rate, blood lactate and glucose levels in short term intensive exercise. Serbian Journal os Sport Sciences 2011; 5 (1): 29-34.

6. Sapata KB, Fayh A, Oliveira A. Effect of prior consumption of carbohydrate on the glycaemia and performance. Rev Bras Med esporto 2006; 12 (04).

7. Kreider RB, Wilborn CD, Taylor L, Campbell B, Almada AL, Collins R,Cooke $\mathrm{M}$, et al. ISSN exercise \& sport nutrition review: research \& recommendations. Journal of the International Society of Sports Nutrition 2010.p. 1-43.

8. Sizer F, Whitney E. Nutrition concepts and controversies. 10th Ed. USA : Thomson Wadsworth; 2006. p. 359-92.

9. Dorfman L. Nutrition for exircise and sports performance. In: Mahan LK, Sylvia Escott-Stump S, editors. Krause's food, nutrition, \& diet therapi. 12 th ed. Philadelphia: Saunders Elsevier, Inc; 2012.p. 508-13.

10. Stang J,Larson N. Nutrition In Adolescence. In: Mahan LK, Escott-Stump S, editors. Krause's Food And Nutrition Therapy. 12th ed. USA : Saunders Elsevier, Inc ; 2012. p. 410-16.

11. Kerksick C, Harvey T, Stout J, Campbell B, Wilborn C, Kreider R, et al. International society of sports nutrition position stand: nutrient timing. Journal of the International Society of Sports Nutrition 2008; 5 (17).

12. Guerra I, Chaves R, Barros T, Tirapegui J. The influence of fluid ingestion on performance of soccer players during a match. Journal of Sports Science and Medicine 2004; (3) : 198-202

13. Bahri S, Sigit JS, Aprianto T, Syafriani R, Dwita L, Octaviar Y. Penanganan rehidrasi setelah olahraga dengan air kelapa (cocos Nucifera L.), air kelapa ditambah putih, minuman suplemen, dan air putih. Jurnal Matematika \& Sains 2012; 17 (1).

14. Davidson GW, McClean C, Brown J, Madigan S, Gamble D, Trinick T, Dully E. The effects of ingesting a carbohydrate electrolyte beverage 15 minutes prior to high-intensity exercise performance. Research In Sport Medicine 2008; (16) : 155-66. 
15. Guyton C, Hall JE. Buku ajar fisiologi kedokteran. edisi 11. Penerbit buku kedokteran: 2007; p1111123

16. Anggaraini AD, Murbawani EA. Pengaruh konsumsi minuman madu terhadap kadar glukosa darah atlet sepak bola remaja selama simulasi pertandingan. 2013

17. Brouns F, Bjorck I, Frayn KN, Gibbs AL, Langs V, Slama, Wolever S. Glycaemic index methodology. Nutrition Research Reviews (2005); (18) :145-71

18. Matthew,L. Goodwin. Blood Glucose Regulation during Prolonged, Submaximal, Continuous Exercise: A Guide for Clinicians, 2010; 4 (3) 694702.

19. Miharja L. Sistem energi dan zat hgizi yang diperlukan pada olahraga aerobik dan anaerobik: Gizi Medik Indonesia. Perhimpunan Dokter Gzi Medik Indonesia. Vol3. 2004. H.9-13

20. Pritchett K, Bishop P, Pritchett R, Kovacs M, Davis JK, Casaru C, Green M. Effects of timing of pre-exercise nutrient intake on glucose responses and intermittent cycling performance. SAJSM 2008; 20 (3).

21. Widiyanto. Glukosa Darah Sebagai Sumber Energi, Fakultas Ilmu Keolahragaan Universitas Negeri Yogyakarta, Majora FIK UNY; 2008, [serial online] [dikutip 2013 May 5]. Tersedia URL: .uny.ac.id [pdf] 